\title{
Analysis of Vegetation Density Using Landsat 8 Imagery for Mapping Characteristics of Green Open Space in Denpasar City
}

\author{
I Ketut Putrajaya $^{1}$, I Putu Hendra Mas Martayana² \\ \{ketut.putrajaya@undiksha.ac.id ${ }^{1}$, mas.mertayana@undiksha.ac.id ${ }^{2}$ \} \\ Universitas Pendidikan Ganesha, Indonesia ${ }^{12}$
}

\begin{abstract}
The development of an urban area has led to changes in land use which have an impact on the existence of green open spaces as one of the city's ecosystems to be less attention. Observation of green open space conditions by utilizing remote sensing technology is an important thing to do so that optimal development planning strategies can be carried out. This study aims to analyze the relationship between vegetation index values with vegetation density and to analyze the distribution characteristics of green open spaces in Denpasar City. The vegetation index transformation used is the Normalized Difference Vegetation Index (NDVI) and the Soil Adjusted Vegetation Index (SAVI). Linear regression analysis is used to determine the relationship between the vegetation index and vegetation density as a consideration in determining the availability of green open space. The results showed that the NDVI transformation produced a better correlation value $\left(\mathrm{R}^{2}\right)$ of 0.842 compared to SAVI of 0.826 . The results of the accuracy test of vegetation density mapping showed a level of accuracy of $90 \%$ and it was obtained that the green open space area reached $4,872.34 \mathrm{Ha}$ or $38.92 \%$ of the area of Denpasar City. If this condition does not find a solution, it is feared that the availability of green open space will continue to decrease, so this research is important to do in order to provide information on existing green open spaces.
\end{abstract}

Keywords: Vegetation Index; Landsat 8; Green Open Space

\section{Introduction}

Urban areas are places for the development of social, cultural and economic activities in which there is a concentration of a number of people as actors of activities. The development of an urban area is marked by the development of the human population which is accompanied by physical facilities and infrastructure such as housing, transportation, industry, etc. which functions as a support for the activities of the population in the city which also experience development (Santillan, et al, 2019).

The development of an urban area has led to changes in land use which have an impact on the existence of green open space as one of the city ecosystems to be less attention, although the existence of green open space is expected to overcome environmental problems in urban areas. In the early stages of urban development, most of the land was green open space. However, with the increasing need for space and land to accommodate residents and their activities, these green open spaces tend to undergo land use conversion into built-up areas. The increase in land needs can be viewed from two main phenomena in urban areas, namely the expansion of built-up areas in non-built areas 
and the occurrence of building densification in built areas. Many urban dwellers are moving towards the suburbs and directly lead to an increase in the population in the suburbs. The suburban area of Denpasar, Bali Province is one of the suburbs that experience the phenomenon of centrifugal urbanization [2].

Denpasar City as the capital city of Bali Province is experiencing development in terms of urban development and increasing population. The population growth rate of Denpasar City in 2012 was $3.72 \%$, with a population density of 6,534 people per $\mathrm{km}^{2}$, making Denpasar City with the highest density in Bali Province. This has led to a change in land use with green vegetation cover into built-up land, and it is feared that it will affect the quality of the environment. Realizing this situation, a sustainable urban environmental arrangement is very important. The presence of vegetation in urban spatial planning is necessary to maintain the balance of high levels of air pollution, so that efforts are needed to develop green open spaces that effectively support human life [3].

Green Open Space, hereinafter abbreviated as green open space, is a longitudinal/lane and/or grouped area, which is used more openly, a place to grow plants, both those that grow naturally and those that are intentionally planted (RI Law No. 26 of 2007 on Spatial Planning). Referring to these regulations, developing green open space is an important thing to do. The proportion of $30 \%$ is expressed as a minimum measure to ensure the balance of the ecosystem. This is of course still relative in nature, so it needs to be studied in depth, especially with regard to aspects of the functions and benefits of green open space. Green open space has functions that can support the realization of a good environment, including ecological, social, economic and architectural functions (Dikman, et al 2019). Green open space has a very important role in protecting and enhancing the natural environment, also long term advantages [5]. The green open space is an important element in the development of sustainable development. Green open space is a concept in multidisciplinary sciences as its definition is understandable in various perspectives. The development of green open space requires good planning and management so that the green open space functions can be realized optimally [6]. Fulfilling green open space needs is an important thing to do. Rushayati, et al, 2011 stated that green open space should be built to lower air temperature and to create a comfortable micro climate.

Rapid and accurate monitoring is required to determine the availability of green open space in an area. Information from remote sensing satellite imagery will be faster and more efficient about the location, distribution and area of green open space which is very helpful in development planning. Sutanto, 2012, argues that the main task of remote sensing is to present information on the earth's surface quickly for even a large area. The availability of Landsat 8 satellite imagery which has a spatial resolution of 30 meters has opened up opportunities to obtain information on the characteristics of green open space availability. Landsat 8 imagery has not been widely used by the government at the district / city level to map natural resources in an area, so this is another consideration in conducting this research. Remote sensing data processing is expected to be able to provide information quickly and precisely related to the characteristics of green open space that can be used for urban development planning ( $\mathrm{Li}$, et al 2015).

The analysis of remote sensing data that will be developed in this research is the transformation of the vegetation index which will produce a value known as the vegetation index value. The vegetation index value is a value that is generated through algorithms or mathematical equations from several bands (channels) contained in remote sensing data. The vegetation indices used in this study are NDVI (Naturalized Difference 
Vegetation Index) and SAVI (Soil Adjusted Vegetation Index), so the bands used are the red (visible) band and the near infrared (near infrared) band. Vegetation index values can provide information on the percentage of vegetation cover, leaf area index, plant biomass, fAPAR (fraction of Absorbed Photosynthetically Active Radiation), photosynthetic capacity and estimated absorption of carbon dioxide (CO2) (Horning, 2004; Ji and Peters , 2007) in (As-Syakur, 2009). The main purpose of this study was to analyze the relationship between vegetation index values and vegetation density, and this study also tried to analyze the characteristics of green open space based on vegetation density in Denpasar City.

\section{Method}

This research was conducted in Denpasar City, Bali Province, which is located at coordinates $08^{\circ} 35^{\prime} ' 31$ "S - 08 44' 49"S and $115^{\circ} 10^{\prime} 23^{\prime \prime E}-115^{\circ} 16^{\prime} 27$ "E. The data used are Landsat 8 OLI imagery for vegetation density extraction, RBI Digital Maps and supported by secondary data and field check results. The research tools used include GPS, meter and supported by ENVI 4.5 and ArcGIS 10.3 software. The research phase begins with correcting satellite images. Radiometric correction is carried out in three stages, namely, at-sensor radiance, at-sensor reflectance and at-surface reflectance. Geometric correction uses the image to map method based on the RBI Digital Map. Pixel relocation uses a polynomial algorithm with interpolation of the nearest neighbor's spectral values. After the satellite image is corrected, the vegetation index transformation is carried out. The transformation of the vegetation index in this study aims to change the pixel value of the Landsat 8 OLI image so as to produce an image with a new pixel value that represents vegetation variation which will then be associated with the availability of green space. This research uses 2 vegetation indices, namely NDVI (Normalized Difference Vegetation Index) and SAVI (Soil Adjusted Vegetation Index). The formulation is as follows.

$$
\begin{aligned}
\text { NDVI } & =\frac{\rho_{2}-\rho_{1}}{\rho_{2}+\rho_{1}} \\
\text { SAVI } & =\frac{\rho_{2}-\rho_{1}}{\rho_{2}+\rho_{1}+L} \times(1+L)
\end{aligned}
$$

Descriptions:

$\rho_{1}=$ Red Band

$\rho_{2}=$ NIR Band

$\mathrm{L}=$ Soil Calibration Factor 0.5 (Huete and Liu, 1994 in Jensen, 2000).

The regression results that have the best correlation value are used as an equation to produce a vegetation density map and its accuracy is tested. The sample determination refers to the method proposed by Justice and Townshend (1981) in Mc Coy, 2005) that determines the vegetation density sample using the smallest pixel unit, namely:

$$
A=P(1+2 L)
$$

Descriptions:

$\mathrm{A}=$ minimum sample size

$\mathrm{P}=$ image pixel size

$\mathrm{L}=$ location accuracy of 0.5 pixels 
The approximate location accuracy in a $30 \mathrm{~m}$ medium resolution image is 0.5 pixels so that the sample size in the field with Landsat 8 OLI image data is $60 \times 60 \mathrm{~m}$, requiring 4 pixels of vegetation density samples based on the distribution of NDVI and SAVI values classified based on the histogram. The method used in sampling is the stratified random sampling. The availability of green open space was analyzed based on the Vegetation Density Map derived from the results of the regression analysis of the vegetation index with the vegetation density of the field measurements. The higher the range of vegetation index values, the higher the vegetation density, the vegetation density also affects the type of green space.

\section{Result and Discussion}

The vegetation density value is derived from a model that is built between the vegetation index value and the vegetation density measured in the field, which is called a linear regression analysis. Based on the regression analysis, the NDVI vegetation index produced a correlation value with a slightly better difference, namely 0.842 compared to SAVI of 0.826 . This indicates that both the NDVI and SAVI vegetation indices have a strong correlation to the percentage of vegetation density as a result of field measurements. NDVI is the most common formula to calculate value of vegetation index (NDVI) give information related to primary production of vegetation [13]. Vegetation index is one of the most useful and used index to quickly identify vegetated areas with the use of multispectral remote sensing data (Zaitimah, et al, 2018). NDVI has higher sensitivity corresponding with crown density change than other vegetation index Normalized Difference Vegetation Index transformation is one of the most representative vegetation indices in presenting vegetation phenomena and has high variability [15]. Maiti and Acharya, 2018 also used NDVI in mapping rice cropping with Landsat 8 and very effective results. Based on the results of the linear regression model, it can then be decided that the NDVI image is derived into a vegetation density map by calculating the pixel value in the NDVI image using the equation $y=166.61 \mathrm{x}-0.1442$.

Table 1. Green Cover Based on NDVI Transformation

\begin{tabular}{llllll}
\hline No & NDVI Value & $\begin{array}{l}\text { Area } \\
(\mathrm{Ha})\end{array}$ & $\begin{array}{l}\text { Percentage } \\
(\%)\end{array}$ & $\begin{array}{l}\text { Vegetation } \\
\text { Density }(\%)\end{array}$ & Category \\
\hline 1 & $\leq-0,1298$ & $7.648,01$ & 64,84 & - & $\begin{array}{l}\text { Non Green } \\
\text { Open Space }\end{array}$ \\
2 & $-0,1298-0,0345$ & $2.279,69$ & 19,33 & $<25$ & Very Low \\
3 & $0,0346-0,1989$ & 724,30 & 6,14 & $25-50$ & Low \\
4 & $0,1990-0,3633$ & 974,94 & 8,26 & $51-75$ & Moderate \\
5 & $\geq 0,3634$ & 169,11 & 1,35 & $>75$ & High
\end{tabular}

(Source: Data Processing, 2020)

Based on the description above, the availability of green open space in Denpasar City through the analysis of vegetation density obtained an area of 4,872.34 hectares or $38.92 \%$ of the area of Denpasar City. Spatially, the distribution of each vegetation density can be seen on the Map of Vegetation Density Denpasar City.

The resulting vegetation density map needs to be tested for accuracy so that the information produced truly represents the actual conditions in the study area. The accuracy test was carried out at 20 sample points that were evenly distributed, but the 
samples taken represented the variation in the vegetation density of Denpasar City. The following is Table 2 for testing the accuracy of vegetation density mapping.

Table 2. Accuracy Test of Vegetation Density Mapping

\begin{tabular}{|c|c|c|c|c|c|c|c|c|}
\hline \multicolumn{2}{|c|}{$\begin{array}{l}\text { Vegetation } \\
\text { Density }\end{array}$} & \multicolumn{5}{|c|}{ Field Check } & $\begin{array}{l}\text { Number of } \\
\text { Sampel }\end{array}$ & $\begin{array}{l}\text { Correct } \\
\text { Sample }\end{array}$ \\
\hline \multirow{6}{*}{ 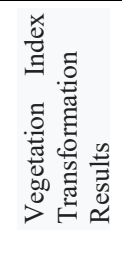 } & & $\mathrm{A}$ & B & $\mathrm{C}$ & $\mathrm{D}$ & $\mathrm{E}$ & & \\
\hline & A & 3 & & & & & 3 & 3 \\
\hline & B & & 3 & & & & 3 & 3 \\
\hline & $\mathrm{C}$ & & & 3 & & & 3 & 3 \\
\hline & $\mathrm{D}$ & & & 1 & 5 & & 6 & 5 \\
\hline & $\mathrm{E}$ & & & & 1 & 4 & 5 & 4 \\
\hline Jumlah & & 3 & 4 & 4 & 6 & 4 & 20 & 18 \\
\hline
\end{tabular}

(Source: Data Processing and Field Checks, 2020)

Keterangan:

A $=$ Non Green Open Space

$\mathrm{B}=$ Very Low Vegetation Density

$\mathrm{C}=$ Low Vegetation Density

$\mathrm{D}=$ Moderate Vegetation Density

$\mathrm{E}=$ High Vegetation Density

$$
\begin{gathered}
\text { Accuracy }(\%)=\frac{\text { Correct Sample }}{\text { Total Sample }} \times 100 \\
\quad=\frac{18}{20} \times 100 \\
=90 \%
\end{gathered}
$$

Green cover based on NDVI value it can be argued that spatially the distribution of vegetation density starts from very low density which is spread in residential or urban center areas, then the low vegetation density starts to spread to the suburban areas, on the contrary the vegetation density is medium to high density distribution has been concentrated in coastal areas and urban periphery areas. This indicates that the area is an area where vegetation still dominates compared to built-up land. Vegetated areas certainly have different densities, starting from the very low vegetation density which dominates the study area with an area of $2,162.75$ hectares or $17.27 \%$, then followed by low vegetation density with an area of $1,565.54$ hectares or 12.50 hectares. $\%$ and moderate vegetation density with an area of 974.94 ha or $7.79 \%$ of the area of Denpasar City. On the other hand, high vegetation density has a much lower percentage than the previous three vegetation densities, namely with an area of 169.11 hectares or $1.35 \%$ of the area of Denpasar City. Based on the description above, it can be concluded that Denpasar City has a very low to low scale vegetation density which is higher than that of medium-high scale vegetation density. The availability of green open space in Denpasar City through analysis of vegetation density from the vegetation index resulted in an area of green open space $4,872.34$ hectares or $38.92 \%$ of the area of Denpasar City. Based on the NDVI transformation and the results of field measurements, a vegetation index value is obtained which can be used as a reference in determining the types of green open space as shown in the following table.

Tabel 3. The Relationship between NDVI Value and Type of Greenspace

\begin{tabular}{llll}
\hline No & NDVI Value & Density & Type of Green Open Space \\
\hline 1 & $-0,1298-0,0345$ & Very Low & $\begin{array}{l}\text { Office/home yard, grass, rice fields before } \\
\text { planting, }\end{array}$
\end{tabular}




\begin{tabular}{llll}
2 & $0,0346-0,1989$ & Low & tomb, green roads, rice fields \\
3 & $0,1990-0,3633$ & Moderate & $\begin{array}{l}\text { Mangrove forests, river borders, rice fields } \\
\text { City forest, city park, mature rice fields, } \\
\text { river border paths }\end{array}$ \\
\hline
\end{tabular}

(Souce: Data Processing, 2020)

The types of green open space based on the NDVI value and the density of vegetation, if related to the percentage of green open space in Table 3, can be grouped between public green open space and private green open space. Public green open space has a density from low, medium to high, with the type of green open space consisting of cemeteries, green roads, mangroves, river borders, urban forests and city parks. The percentage of area reached $18.45 \%$, this figure was obtained after reducing green open space for rice fields because basically rice fields are still classified as private green open spaces. Private green open space has a very low density level with the type of green open space including office / house gardens, grass, and added with rice field type green open space. The area percentage of private green open space reached $20.47 \%$. If you pay attention to Law of the Republic of Indonesia no. 26 of 2007, which recommends $20 \%$ public green open space and $10 \%$ private green open space, then the condition of green open space in denpasar city is still classified as unbalance. After knowing the types of green open space based on NDVI values and vegetation density, it is important to differentiate between green open space and non green open space. The purpose of distinguishing between green open space and non green open space is to create a green open space distribution map which is then used to analyze the green open space distribution pattern in Denpasar City, whether it tends to be clustered, spread out or elongated. Clarifying this statement, a map of the distribution of green open space for the city of Denpasar (Figure 1).

Based on Figure 1. related to the Map of Green Open Space, it can be argued that the existence of green open space in Denpasar City tends to spread to urban areas to the southern coastal areas of Denpasar City. This indicates that the suburban areas have not experienced significant settlement compaction, even though these areas have the potential to experience increasingly rapid settlement development. Especially for suburban areas, the dominating green open space is the type of rice fields such as rice fields, mixed plantations and so on. In contrast to the southern coastal areas, which are mangrove forest areas which also require attention so that their existence is maintained, they can be fugreen open spaceer developed. Settlement compaction tends to be centered in the inner city or occurs in the central part of the city. This condition becomes a consideration in determining the priority of green open space development, so that the green open space that is developed is right in the area that really needs additional green open space. Similar research has also been conducted by [17] which examines the determination of oxygen-based green open space in Denpasar City. Pussella and Li, 2019 stated that urban green parks perform a remarkable role for the physical, social and psychological wellbeing of the urban public by providing space for relaxation and recreation, directly influencing public health through mitigation of the urban heat impact, noise reduction and moderation of air and water pollution. This Concurs with research by Ullah et al., 2019 stated that Green parks are vital public spaces and play a major role in urban living and well-being. Research on the attractiveness of green parks often relies on traditional techniques, such as questionnaires and in-situ surveys, but these methods are typically insignificant in scale, time-consuming, and expensive, with less transferable 
results and only site-specific outcomes, so it is important to carry out monitoring using remote sensing data especially Landsat 8 Imagery.

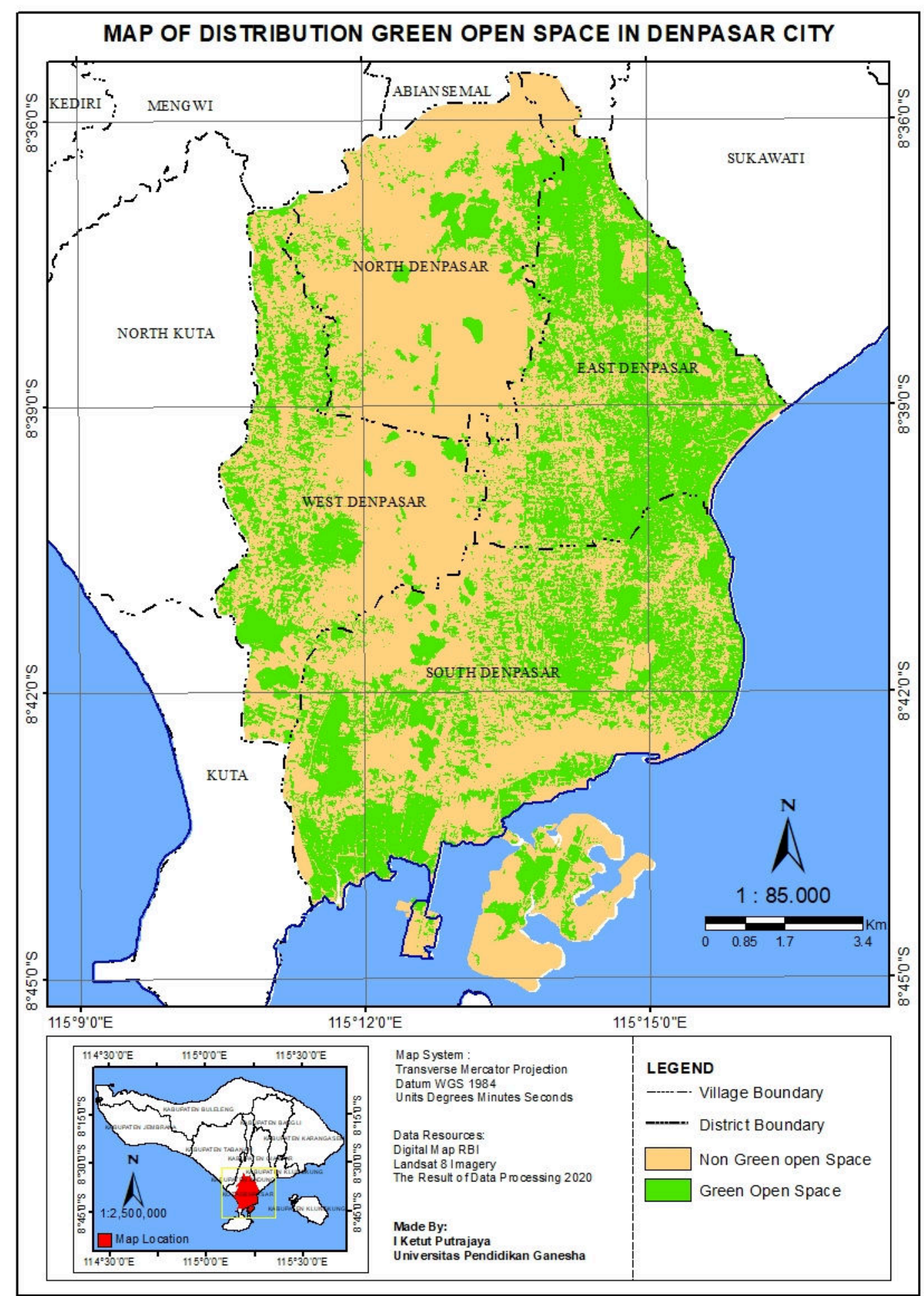

Figure 1. Map of Distribution Green Open Space in Denpasar City 


\section{Conclusion}

Based on the results and discussion that has been described, it can be concluded that the analysis of Landsat 8 OLI Image to determine vegetation density through NDVI transformation produces a correlation value $\left(\mathrm{R}^{2}\right)$ which has a slight difference of 0.842 compared to SAVI of 0.826 . However, it can be determined that the NDVI transformation results are used in analyzing vegetation density. Variations in the characteristics of vegetation density in Denpasar City can be argued that non-vegetated areas are more dominant, namely with an area of 7,648.01 hectares or $61.08 \%$ of the area of Denpasar City, compared to vegetated areas which have an area of only 4,872.34 hectares or 38.92 $\%$ of the area of Denpasar City. A study of green open space using Landsat 8 imagery in order to obtain better results needs to consider the following points. Selection of a better transformation method in order to produce better green open space information with high accuracy. The use of satellite imagery with high spatial resolution allows for detailed land use classification so that the determination of the type of green open space can be done properly in each land use unit.

\section{References}

[1] J. . Santillan, A. . Amora, M. Makinano, A. . Gingo, and J. . Marqueso, "Analyzing the impacts of land cover change to the hydrologic and hydraulic behaviours of the philippines' third largest river basin," Isprs Ann. Photogramm. Remote Sens. Spat. Inf. Sci., vol. 4, no. 3, pp. 41-48, 2019.

[2] P. I. Christiawan, "Designing the Mitigation Model of Urban Sprawl Potential Impact in Suburban Denpasar, Bali," J. Physic Conf. Ser., vol. 1363, no. 1, 2019.

[3] P. I. Christiawan, "Cultural landscape: a bridge between deforestation and local community?," J. Landsc. Ecol., vol. 11, no. 2, pp. 77-87, 2018.

[4] M. Dikman, D. Ishara, L. Dirk, Z. Chris, and P. Assela, "No Title," Atmosphere (Basel)., vol. 10, no. 3, p. 151, 2019.

[5] R. H. Manan, "Policy Analysis of Urban Green Open Space Management in Jakarta City, Indonesia," Int. J. Enginering Res. Technol., vol. 5, no. 4, pp. 241248, 2016.

[6] S. H. Atiqul, "Urban Green Spaces and an Integrative Approach to Sustainable Environment," J. Environ. Prot. (Irvine,. Calif)., vol. 2, no. 5, pp. 601-608, 2011.

[7] S. . Rushayati, H. . Alikroda, E. . Dahlan, and H. Purnomo, "Development of Green Open Space based on Surface Temperature Distribution in Bandung Regency," (in Bahasa) Forum Geogr., vol. 25, no. 1, pp. 17-26, 2011.

[8] Sutanto, Remote Sensing Research Methods (in Bahasa). Yogyakarta: Ombak, 2012.

[9] X. Li, C. Zhang, and W. Li, "Does the visibility of greenery increase perceived safety in urban areas? Evidence from the place pulse 1.0 dataset," Isprs Int. $J$. geo-information, vol. 3, no. 4, pp. 1166-1183, 2015.

[10] A. . As-Syakur, "Vegetaion Index Analysis Using ALOS AVNIR-2 Image and Geographical Information System (GIS) for Spatial Evaluation of Denpasar City," (in Bahasa) J. Bumi Lestari, vol. 9, pp. 01-11, 2011.

[11] J. . Jensen, Remote sensing of The Environmental Eagreen open space Resource Perspective. New Jersey-USA: Prentice Hall., 2000.

[12] R. . Mc Coy, Field Methods in Remote Sensing. New York: The Guildford Press, 
2005.

[13] Liu Ting, "Mapping Vegetation in an Urban Area with Stratified Clasification and Multiple Endmember Spectral Mixture Analysis," Remote Sens. Environ., vol. 133, pp. 251-264, 2012.

[14] A. Zaitimah, Samsuri, A. . Ahmad, and R. . Safitri, "Normalized difference vegetation index (ndvi) analysis for land cover types using landsat 8 oli in besitang watershed, Indonesia," J. Earth Environ. Sci. Conf. Ser., vol. 126, no. 1, pp. 01-09, 2018.

[15] Yuan Fei, "Comparison of Impervious Surface Area and Normalized Difference Vegetation Index as Indicators of Surface Urban Heat Island Effects in Landsat Imagery," Remote Sens. Environ., vol. 106, pp. 375-386, 2007.

[16] A. Maiti and P. Acharya, "Mapping rice cropping system in the lower gangetic plain using landasat 8 (oli) and modis imagery," Int. Arch. Photogramm. Remote Sens. Spat. Inf. Sci., vol. XLII, no. 5, pp. 271-274, 2018.

[17] I. K. Putrajaya, "Accuracy of alos avnir-2 image technology for mapping oxygen need and green open space priority in denpasar city, bali," J. Eng. Aplied Sci., vol. 13, no. 10, pp. 3594-3600, 2018.

[18] P. R. G. N. . Pussella and L. Li, "Identification and assessment of the driving forces for the use of urban green parks and their accessibility in Colombo, Sri Lanka, through analytical hierarchical processing," Geospat. Health, vol. 4, no. 1, 2019.

[19] H. Ullah, W. Wan, S. . Haidery, N. . Khan, Z. Ebrahimpour, and T. Luo, "Analyzing the Spatiotemporal Patterns in Green Spaces for Urban Studies Using Location-Based Social Media Data," ISPRS Int. J. Geo-Information, vol. 8, no. 11, p. 506, 2019. 